ROCZNIKI NAUK PRAWNYCH

Volume XXVIII, number 2 - 2018

E n g 1 is h ve r s i o n

DOI: http://dx.doi.org/10.18290/rnp.2018.28.2-6en

VIKTORIA SERZHANOVA

\title{
SUPREME COURT SYSTEMS IN THE NORDIC COUNTRIES. AN OUTLINE OF THE ISSUE
}

\section{INTRODUCTION}

The condition for correct and effective functioning of each society is the observance of certain patterns of behaviour by the citizens. Essentially, a democratic system ${ }^{1}$ stimulates people's propensity to or even creates the need for pursuing common, socially useful goals and benefits. As a consequence, citizens only accept the rules of behaviour that have specific common goals. Compliance with certain standards of behaviour and the application of appropriate civil and criminal sanctions for their violation are both an element and a prerequisite for the proper functioning of public institutions and, consequently, for the effectiveness of the state apparatus, which guarantees the functioning of society in a democratic political system. ${ }^{2}$

Rules of conduct and the actual procedure are very important for the effective application and enforcement of substantive law. The organisation and conduct of the courts should, in essence, be appropriate and relevant to the decisions they issue ${ }^{3}$. Proceedings before a court should make it possible to

VikTORIa Serzhanova, PhD, Hab, is an associate professor of the University of Rzeszów. She is the head of the Department of Political Systems of European Countries, Faculty of Law and Administration of the University of Rzeszów; address:Al. Rejtana 16C, 35-969 Rzeszów, Poland; e-mail: viktoria@ur.edu.pl.

${ }^{1}$ The characteristics and mechanisms of democratic governance have been analysed in depth in V. SERZHANOVA and S. SAGAN, Nauka o państwie wspótczesnym (Warszawa: LexisNexis, 2013), 163ff.

${ }^{2}$ This issue is explored in depth in P.H. LindBlom, "The Role of the Supreme Courts in Scandinavia," Scandinavian Studies in Law 39 (2000): 332ff.

${ }^{3}$ For more on the principles governing the creation and internal structure of state authorities, and on the principles of the organisation and functioning of the judiciary, also stemming from 
settle disputes in such a way as to compensate adequately for the losses incurred by each party, with due regard to their interests in the administration of justice. ${ }^{4}$

There is no doubt that supreme courts play a very important role in judicial systems. In the Nordic countries, their tasks-both in doctrine and practice-are seen slightly differently than those known in the systems of continental Europe. This study attempts to provide a comparative study of the supreme courts functioning in the Nordic countries. I will focus primarily on the tasks, objectives, and roles of the supreme courts in the Nordic countries, as well as the principles of organisation and functioning underlying the supreme court systems in this European region. A considerable part of the study covers the identification of common features as well as differences which are apparent when the countries of the eastern and western Nordic legal cultures are compared.

\section{FUNCTIONS OF SUPREME COURTS IN THE NORDIC COUNTRIES}

In the Nordic countries, all courts, including the supreme courts, are primarily responsible for the administration of justice in civil and criminal proceedings. They also carry out the task of enforcing limited forms of political control through judicial review of normative acts and administrative acts and decisions. In Finland, this control function is limited to administrative acts and decisions.

Overall, in the Nordic countries, the operation of courts, or, put differently, proceedings before the courts fulfil four basic functions (goals), which sometimes intertwine or overlap: conflict resolution, behavioural change, political control and lawmaking through jurisprudence. In Sweden, particular attention is paid to behavioural change, which is a public function, while ongoing discussion on this issue in the Western Scandinavian countries (Norway, Denmark, Iceland) emphasises the dominating role of goals that have a private character. Proponents of this view see coexistence and mutual relations holding between the function of conflict resolution and behavioural change, which are equally important elements contributing to the realisation

European standards, see Organy i korporacje ochrony prawa, ed. V. Serzhanova and S. Sagan (Warszawa: LexisNexis, 2014), 3ff.

${ }^{4}$ More detailed reflections on this subject can be found in V. SERzhanova, "Sądy w państwach nordyckich," in Sadownictwo w Europie w XIX i XX wieku, ed. E. Leniart, R. Świrgoń-Skok, and W.P. Wlaźlak (Kraków: Bikstudio Krzysztof M. Szwaczka, 2016), 147-67. 
of the greatest values contained in substantive law, both in the public and private senses. $^{5}$

Apart from common courts, supreme courts undoubtedly and manifestly perform the general function of providing judicial procedure, which, ultimately, consists in implementing the content of substantive law by resolving conflicts and changing human behaviour. The importance attached to these functions in both civil and criminal proceedings influences the tasks which the supreme courts in the Nordic countries are faced with.

While the role and goals of the supreme court in the literature on the subject are spelt out clearly in the literature, ${ }^{6}$ the question of two tasks for which they were established is debatable. Namely, one of them is a private goal, which is to enable the losing party to file a suit again, which may result in a final decision that is in line with the essence of lawful administration of justice (the so-called individual aspect of justice). The other task is a goal that has a public dimension, which is to issue a judgement serving as a guideline for future similar cases (the so-called reorientation of case law). These tasks are important because they enable the enforcement of the content of substantive law and they ensure that a fair trial is conducted at both private and public level.

Notwithstanding the opinions on the essence of court proceedings (be it conflict resolution, modification of behaviour, crime control or a fair trial), the prerequisites for the admissibility of cases heard before the supreme court will depend on whether its task is to implement the individual aspect of administration of justice or to reorient the future case law. The individual dimension of administration of justice and reorientation of case law can interact with each other in the same way that conflict resolution interacts with behavioural change. This is probably not a coincidence but a consequence of the fact that, on the one hand, the functions of courts, including supreme courts, are, or at least should be, convergent. It seems, however, that the functions of the supreme court are more important. This argument is valid when a particular state is relatively small or when its supreme court is relatively large to be able to deal with all cases that are registered with it. None of the Nordic countries is such, not even Iceland.

\footnotetext{
${ }^{5}$ Such a position is presented, among others, in LinDBLOM, "The Role," 337. For a broader and more detailed description of the functions of court proceedings in the Nordic tradition in Polish literature, see SERZHANOva, Sady w państwach, 147-67.

${ }^{6}$ LindBLom, "The Role," 337-49, analyses the objectives and role of the Supreme Courts in Scandinavia and their private and public aspects thoroughly, competently and in great detail.
} 
The differences between the general purpose of judicial proceedings and the task for which the supreme court is established relate to the quantitative aspect rather than the qualitative one. Matters such as the burden of proof, the duration of proceedings, joint proceedings, the active role of courts in proceedings, costs of proceedings, etc. are regulated in different ways depending on the procedural model. For example, if the priority of a trial is to change someone's behaviour, then regulations concerning the duration of the proceedings, ${ }^{7}$ the involvement of the court or the heavy burden of proof may be liberal.

The supreme courts in the Nordic countries are organised and operate primarily on the basis of different legal regulations, resulting from the different treatments of the system of common judiciary and diverse procedures. ${ }^{8}$ What they have in common, however, is the principle of two-instance court proceedings. Additionally, the activities of supreme courts are also based on certain common principles, such as the principle of orality of judicial proceedings, as well as additional rules and standards developed in practice, such as requests for the case to be heard, the possibility of reviewing the judgement, etc. Organisational and procedural differences somehow result in different constitutional tasks for which the supreme courts in Scandinavia were established. Conversely, the different ranges of functions enshrined in Nordic constitutions for the supreme courts entail different structures of, first and foremost, the common courts, but also the supreme courts, since this dependence is mutual. These differences, however, do not call into question the main tasks for which the courts were appointed. ${ }^{9}$

\footnotetext{
${ }^{7}$ Interesting reflections on the duration of the judicial process and in particular on measures to reduce the length of court proceedings in the Nordic countries can be found in a comprehensive study prepared for the Council of Europe European Commission for the Efficiency of Justice (CEPEJ) by M. SMOLEJ and J.T. Johnsen, Time Management of Justice Systems: a Northern Europe Study, available in the English language at https://www.coe.int/t/dghl/cooperation/cepej/Delais/ Gestion Temps_en.pdf, accessed January 18, 2018.

${ }^{8}$ See D. TAmm, "Nordic Supreme Courts - Differences and Similarities," in Rule of LawDevelopment and Judicial Reform (Beijing: Social Sciences Academic Press China, 2016), 112-20; also IDEM, "Nordic Unity and Nordic Supreme Courts: Differences and Similarities," in Unity and Plurality in the Legal History of the Baltic Sea Area, ed. M. Luts-Sootak, S. Osipova, and F.L. Schäfer (Frankfurt am Main-Bern-Bruxelles-New York-Oxford-Vienna: Peter Lang, Internationaler Verlag der Wissenschaften, 2012), 287-94.

${ }^{9}$ For more information, see LindBLOM, “The Role," 327-28ff.
} 


\section{COMMON FEATURES THAT CHARACTERISE THE SUPREME COURT SYSTEM IN THE NORDIC COUNTRIES}

Despite far-reaching differences, there are a number of essential common features with regard to the role played by the Scandinavian supreme courts. One of the most important is the fact that their organisation and competences are a direct result of the common history of the three western Nordic countries (Norway, Denmark and Iceland) and the two eastern Nordic countries (Sweden and Finland). Western Nordic countries exhibit a number of similarities despite their different sizes and different durations of their statehood. The eastern Nordic countries, on the other hand, despite functioning separately for a long time, in the applied model solutions sometimes seem to be similar to each other.

One of the crucial similarities ${ }^{10}$ is that all Scandinavian supreme courts operate on the basis of normative regulations in the field of civil law, hence the sources of law for them are the provisions contained in relevant acts. The Anglo-Saxon system of precedent law in the Nordic countries does not exist, although it cannot be denied that, in practice, some elements closely resemble it. ${ }^{11}$ Therefore, decisions in precedent cases are not binding for cases pending before other courts and their impact on the judgement in proceedings is negligible. Thus, compliance with the case law of other courts in the strict sense of the word does not occur, although in reality differences in the content of judgements are sometimes minimal or non-existent. Only the decisions of the supreme courts, and the supreme administrative courts in eastern Scandinavia, and to a limited extent other courts of last resort (e.g. the Labour Court and Market Court in Sweden) provide precedents for other courts of lower instance.

Questions and legal issues (with a few exceptions in the western Nordic countries) can be dealt with by all supreme courts, but the assessment of evidence is usually limited or completely prohibited. In the tradition of the Nordic countries there are no courts of cassation because the supreme courts are perceived as appeal courts. ${ }^{12}$ Only the supreme courts of Finland and

\footnotetext{
${ }^{10}$ The similarities between Nordic supreme courts are discussed competently by LINDBLOM, "The Role," 328. From a slightly different perspective, they are also analysed in depth by TAMM, "Nordic Supreme," 114ff.

${ }^{11}$ An in-depth examination of the role of precedents in the tradition of Danish and Norwegian courts is carried out by W.E. von EyBEN, "The Attitude towards Judicial Precedent in Danish and Norwegian Courts," Scandinavian Studies in Law 3 (1959), 53-86.

${ }^{12}$ In Iceland, there is no second instance in the form of separate courts of appeal.
} 
Sweden sometimes restrict themselves to revoking decisions of lower courts in whole or in part and remand cases for reconsideration.

Scandinavia also lacks a tradition of constitutional justice, ${ }^{13}$ but all courts formally have the competence to scrutinise the constitutionality of law, ${ }^{14}$ although in practice this is largely limited. ${ }^{15}$ In a small degree, it exists in Sweden, Finland and Denmark, while in Iceland it has a fairly strong status ${ }^{16}$ and plays an even greater role in Norway. ${ }^{17}$

Judicial control in Norway has a long and deeply rooted tradition, although (or perhaps because of that), like in Denmark or Iceland, it is not subject to constitutional regulations. In the last few decades, Norway has seen a kind of revival of the phenomenon of control by the courts. ${ }^{18}$

\footnotetext{
${ }^{13}$ A. FolLESDAL and M. Wind, "Introduction-Nordic Reluctance towards Judicial Review under Siege," Nordisk Tidsskrift for Menneskerettigheter 27, no. 2 (2009): 131-41.

${ }^{14}$ In the Finnish doctrine, we come across the view that in Finland there is no formal judicial control over the law passed by the parliament. Indeed, it cannot be questioned that in Finland the main burden of controlling the constitutionality of the law lies with the legislator, that is first and foremost with the parliament, since intraparlamentarian control clearly prevails. The provisions of the Basic Law in paras. 106 and 107, despite not referring directly to judicial review, they actually sanction it, allowing common and administrative courts to assess the provisions contained in statutes and statutory acts and their non-application in the event that the court finds them to be inconsistent with statutes and the Constitution. Although the frequency of such distributed control carried out in practice is not impressive, it does not mean that there is no such thing as a complete lack of control or prohibition. I cannot, therefore, fully agree with this view. Interesting and noteworthy considerations on the control of the constitutionality of law in Finland can be found in: J. LAVAPURO, T. OJANEN, and M. SCHEININ, "Rights-Based constitutionalism in Finland and the Development of Pluralist Constitutional Review," International Journal of Constitutional Law 9, no. 9 (2011): 505-31.

${ }^{15}$ Leszek Garlicki writes competently about the activity of constitutional courts and supreme courts related to the control of the constitutionality of law in a comparative perspective. L. GARLICKI, "Constitutional Courts versus Supreme Courts," International Journal of Constitutional Law 5, no. 1 (2007): 44-68.

${ }^{16}$ The debate on the judicial control of the constitutionality of law in Iceland is thoroughly discussed by R. HelgadótTiR, "Nonproblematic Judicial review: A case study," International Journal of Constitutional Law 9, no. 2 (2011): 532-47.

${ }^{17}$ Compare A. BÅRDSEn, The Nordic Supreme Courts as Constitutional Courts: Main Features as Seen from the Norwegian Perspective, Joint Seminar between the Constitutional Court of Austria and the Supreme Court of Norway, Vienna the $29-30^{\text {th }}$ of October 2015, accessed January 18, 2018, https://www.domstol.no/globalassets/upload/hret/artikler-og-foredrag/nordic-constitu tional-courts-vienna-29102015.pdf; R. HIRSCHL, "The Nordic Counternarrative: Democracy, Human Development and Judicial Review," International Journal of Constitutional Law 9, no. 2 (2011): 449-69; also K.M. BruZelius, The Nordic Constitutions and Judicial Review, accessed January 18, 2018, http://www.constcourt.md/public/files/files/files/conferinta_20ani/programul_ conferintei/Karin_Bruzelius_2.pdf.

${ }^{18}$ LinDBLOM, "The Role," 335. For more information in the Norwegian literature, see E. SMiTH, Høesterett og folkestyret. Prøvningsretten overfor lover (Oslo: Universitetsforlaget, 1993), throughout.
} 
In Denmark, in the last two decades, judicial review has also been the subject of discussion. However, it is still contested by some, and as a result applied with extreme caution. ${ }^{19}$

There is no constitutional court in Sweden, and the possibility of judicial review of the constitutionality of the law in a specific case is open to common courts. ${ }^{20}$ In practice, such control is very rarely performed. The condition for not applying the law in a specific case is its incompatibility with the constitution. The Swedish Act on the Form of Government contains a provision from 1979 which states that courts and other authorities are sometimes obliged not to apply a legal provision or a rule of law in a specific case pending before a court. In the case of a statutory provision, they may do so only if the provision is obviously unconstitutional. Sometimes Swedish courts make use of this provision of the constitutional act. ${ }^{21}$ In administrative matters, such control is to be exercised only by the Supreme Administrative Court. ${ }^{22}$ The Act on the Control of Administration Swedish (Rättsprövningslagen) 1988 allows any citizen to bring an action before a court against an administrative decision that is unlawful (not only unconstitutional), and the court may, on that basis, overrule that decision. Thus, the normative powers of the courts are extended by "mass" law-making and the use of general clauses and framework legislation.

In Finland, the common and administrative courts may also not apply the law in a similar way as in Sweden. The legal basis for such a solution are the provisions of paras. 106 and 107 of the Basic Law. The same effect can also be achieved by the courts by interpreting (or creating) a rule or principle of law in a "pro-constitutional" or "human-rights-friendly" manner. This technique is also known in Sweden. ${ }^{23}$

\footnotetext{
${ }^{19}$ Nevertheless, there is a known case where the Supreme Court accepted a complaint for unconstitutionality of the Maastricht Treaty adopted by Denmark. See the judgement of the Supreme Court of Denmark of 22 August 1996, file ref. no. I 272/1994.

${ }^{20}$ The Swedish debate over the judicial control of the constitutionality of law is competently discussed by S. Strömholm, "Goal-Steering and Judicial Review," Scandinavian Studies in Law 40 (2000): 189-97.

${ }^{21}$ See H. STRÖMBERG, "Ett HD-fall om prövning av en förordnings grundslagsenlighet," Juridisk Tidskrift 2 (1996-97): 450-52; J. NERGELIUS, "Om grundlagstolkning, grundlagsvänlig lagtolkning och åsidosättande av grundlagsstridig lag," Svensk Juristtidning 81 (1996): 835-71; LINDBLOM, "The Role," 335.

${ }^{22}$ On the Supreme Administrative Court in Sweden, see "The Swedish National Courts Administration," Scandinavian Studies in Law 51 (2007): 635 and 640. An interesting discourse on the historical judicial review of administrative decisions in Sweden can be found in O. WeSTERBERG, "Judicial Review of Administrative Decisions," Scandinavian Studies in Law 16 (1972): 307-26.

${ }^{23}$ Moreover, not only courts, but also public authorities have the power to assess the compliance of lower-order acts with statute and, if they are found to be inconsistent with the law or the
} 
The number of judges in the supreme courts in the Eastern and Western Scandinavian countries is comparable. Iceland is the only exception, and the trend towards a reduction in the number of judges of the Swedish Supreme Court at the beginning of the century, as the figures show, is currently absent. $^{24}$

\section{DIFFERENCES AMONG THE SUPREME COURT SYSTEMS OF INDIVIDUAL NORDIC COUNTRIES}

One of the basic features of the Nordic supreme judicial systems is that in the eastern Scandinavian countries (Finland ${ }^{25}$ and Sweden $^{26}$ ), with very few exceptions, the supreme courts hear only precedential cases. The supreme courts in the Western Scandinavian countries (Denmark, Iceland and Norway), on the other hand, also hear some cases of a high value for the parties and pass judgements in individual cases which may be perceived as contrary to the spirit of justice. The Danish supreme court is more focused on the most important cases, while the Norwegian Supreme Court is far from being seen as a court issuing judgements of a precedential character. In the absence of appeal courts in Iceland, its supreme court is the second and, at the same time, highest instance. Consequently, the formal requirements for referring a case to the Supreme Court vary from one Nordic country to another. As a general rule, in all Nordic countries it is possible to appeal the decision of the lower court to the highest court. However, it is worth noting that while in Iceland the Supreme Court is the only appeal ${ }^{27}$ court and in Norway only some complaints to the Supreme Court are rejected, in Denmark, Finland and Sweden only a few cases are admitted to the Supreme Court. ${ }^{28}$

constitution, not to apply them. This strategy of the Finnish legislator with respect to the control of the constitutionality of law is quite original, rare and rather unheard of in other countries. It is a manifestation of the eastern Nordic tradition.

${ }^{24}$ The number of supreme court judges in the Nordic countries is currently the following: 16 in Denmark, 20 in Norway, 9 in Iceland, 16 in Sweden, and 19 in Finland.

${ }^{25}$ On the supreme court in Finland, see S. SARvilinNA, "Court Administration in Finland," Scandinavian Studies in Law 51 (2007): 594-95; also J. NouisiaInEN, "The Role of the Finnish Supreme Court in the Legislative Process," Scandinavian Studies in Law 23 (1979): 131-48.

${ }^{26}$ On the supreme court in Sweden, see: The Swedish National, 633 and 638.

${ }^{27}$ On the judicial system in Iceland, including its supreme court, see "Iceland's Judicial System," Scandinavian Studies in Law 51 (2007): 606-7.

${ }^{28}$ LindBLOM, "The Role," 329, examines in depth the different features of Scandinavian supreme courts. 
The eastern Scandinavian countries have administrative courts separate from common courts, with the Supreme Administrative Court at the head (Korkein hallinto-oikeus in Finland, Högsta förvaltningsdomstolen in Sweden, and Högsta förvaltningsdsomstolen in Finland and Sweden, and before 2011 Regeringsrätten in Sweden). ${ }^{29}$ The eastern Scandinavian countries do not know the tradition of administrative judiciary because the handling of complaints against administrative decisions issued by public administration bodies in terms of their legality and, to some extent, legitimacy, is an issue addressed by common courts.

The procedures for appointing supreme court judges are different too, the only common aspect being that in all the Nordic countries these are not elected but nominated, ${ }^{30}$ and they are typically appointed by the head of state (except for Sweden). However, the detailed procedures are different. ${ }^{31}$

In Norway, the judges of the Supreme Court are appointed by the King for life at the recommendation of the government, which is formulated on the basis of a recommendation issued by the Opinion Committee and the opinion of the Supreme Court President submitted to the Minister of Justice, after the candidate has been interviewed by the Opinion Committee, which conducts the competition for the vacant judge's position and also prepares an opinion on the candidate. They may hold their office until the age of 70 .

In Denmark, the Supreme Court judges are appointed by the Queen on the motion of the Minister of Justice, following a recommendation from the Council for the Nomination of Judges, which is based on a recommendation issued by the Supreme Court and is the result of the application of the candidate selected in an open competition. Both recommendations are binding.

\footnotetext{
${ }^{29}$ On the origin and common ground of the creation of the highest administrative judiciary in Sweden and Finland, see T. ModEEN, "The Founding of the Supreme Administrative Court in Finland set Against its Historical Background in Sweden and Finland," Scandinavian Studies in Law 21 (1977): 209-40.

${ }^{30}$ TAмm, Nordic Supreme, 115, writes more about political determinants present in the procedure of appointing judges of supreme courts in the Nordic countries.

${ }^{31}$ The President of the Federal Court of Justice (German Supreme Court), Günter Hirsch, wrote a very detailed report on the case entitled Appointing of Supreme Court Judges. Examination of Situation in Individual Countries, presenting the state of affairs as of May 30, 2006, available at http://network-presidents.eu/sites/default/files/Report_Hirsch_eng[1].pdf, accessed January 18, 2018. See also: The Supreme Court of Norway. Separation of Powers and Independence of Constitutional Courts and Equivalent Bodies, the $2^{\text {nd }}$ Congress of the World Conference on Constitutional Justice, accessed January 18, 2018, http://www.venice.coe.int/WCCJ/Rio/Papers/ NOR_Supreme_Court.pdf.
} 
In Iceland, judges of the Supreme Court are appointed by the President of the Republic in agreement with the Minister of Justice, on the recommendation of the courts. ${ }^{32}$

In Finland, Supreme Court judges are appointed by the President of the Republic upon a proposal from the Council of State (the government) on the basis of a recommendation made by the General Assembly of the Supreme Court containing an opinion on the applicants, submitted to the Minister of Justice.

Finally, in Sweden, Supreme Court judges are appointed by the government. The list of candidates is drawn up by a three-person group of the Supreme Court judges, which is the basis for a debate in the parliament. The President of the Supreme Court submits the Court's proposal to the Minister of Justice, who may also propose his or her own candidate. Once agreement has been reached, the Minister of Justice proposes a candidate to the Riksdag.

When dealing with complaints and issuing judgements, Norwegian Supreme Court judges are largely guided by their own values, while Danish Supreme Court judges may include some "policy" in this respect. ${ }^{33}$ Such tendencies and features are not at all present in the work of supreme courts judges of the eastern Scandinavian countries.

The rules of procedure before the supreme courts (e.g. oral proceedings, processing documentary evidence, voting, etc.) vary considerably from one Nordic country to another.

Preparatory work related to the adoption of normative acts in the field of justice, such as government proposals or reports of parliamentary committees, plays a much greater role as a source of law in the Eastern countries than in the Western Scandinavian countries.

\footnotetext{
${ }^{32}$ Compare Iceland's Judicial, 607; see also R. TRYgGVADÓTTIR and Th. InGADÓTTIR, Researching Icelandic Law, accessed January 18, 2018, http://www.nyulawglobal.org/globalex/Iceland.html.

${ }^{33}$ An in-depth study concerning the activities of the Supreme Court in Denmark is presented in H. ZAHLE, "Judicial Opinion Writing in the Danish Supreme Court (Højesteret)," Scandinavian Studies in Law 51 (2007): 559-80; for a historical perspective on this; see also S. IUUL, "The Danish Supreme Court Through 300 Years," Scandinavian Studies in Law 6 (1962), 163-83. On the organisation of the judiciary in Denmark, including the Supreme Court, see also "The Danish Courts - an Organisation in Development," Scandinavian Studies in Law 51 (2007): 581-90.
} 


\section{CONCLUSION}

The supreme courts in the Nordic countries hold a very high, prestigious position. ${ }^{34}$ Their role and functions are determined by the fact that they are judicial authorities.

From a comparative perspective, the position of Swedish courts has always been quite limited. This has been the case for a number of reasons, such as political arguments for democracy, the principles of equality, a strong belief in the care and control of the state rather than resolution of conflicts in the court, the existence of a large number of diverse alternative mechanisms for dispute resolution and behavioural change, and-from the first half of the $20^{\text {th }}$ century onwards - a fully justified belief that the courts and judges want to take an active part in building a social-democratic welfare state model. All these, and probably a number of other factors, have made the Swedish courts, despite having a relatively high number of judges, much less influential than in other countries.

However, by all accounts, in the coming years the role of courts will be growing. There are many reasons for this. ${ }^{35}$ One of the most important seems to be the fact that despite different opinions on the Montesquieu principle of power division, applied in Scandinavia, the world is moving towards a rather post-Montesquieu concept of mechanisms of mutual control and equilibrium. Another reason may also be the fact that in times of rapid technological and social development, states are creating a huge and growing number of legal regulations that need to be interpreted. The increasing tendency to use legislative techniques based on the creation of framework legislation and general clauses of a very general nature has a similar effect. Finally, following the accession of Denmark to the European Union, and later of Finland and Sweden, the external influence on the national law created in them became much more noticeable - a trend that could be called the juridisation of politics, and at the same time the politicisation of law. Despite the fact that Norway and Iceland are still outside the Union, the impact of these trends from the continent is likely to increase over time. Juridisation therefore seems contagious and the Nordic countries, situated at the ends of the EU, will not avoid it either. Therefore, it seems highly probable that court

\footnotetext{
${ }^{34}$ TAMM, "Nordic Supreme," 115ff, presents an interesting discourse on factors determining the perception of the supreme courts by societies in the Nordic countries.

${ }^{35}$ See more Lindblom, "The Role," 331; IDEM, Studier i procesrätt (Stockholm: Fritzes, 1993), 89ff.
} 
judgements will gradually have an increasing impact on the societies of the Nordic countries, on the development of their economic and social life, and perhaps even on interpersonal relations.

In conclusion, the position of the judiciary, in particular that of the highest courts in the Nordic countries, especially in Finland and Sweden, remains rather limited, at least compared to the situation in the Anglo-Saxon countries. Nevertheless, both its expansion in quantitative and qualitative terms and the gradual unification of the role of courts in Scandinavia can be expected.

\section{BIBLIOGRAPHY}

\section{CASE LAW}

Judgement of the Supreme Court of Denmark of 22 August 1996, file ref. no. I 272/1994.

\section{LITERATURE}

BÅRDSEn, Arnfinn. The Nordic Supreme Courts as Constitutional Courts: Main Features as Seen from the Norwegian Perspective, Joint Seminar between the Constitutional Court of Austria and the Supreme Court of Norway, Vienna the 29-30th of October 2015. Accessed January 18, 2018. https://www.domstol.no/globalassets/upload/hret/artikler-og-foredrag/nordicconstitutional-courts-vienna-29102015.pdf.

Bruzelius, Karin M. The Nordic Constitutions and Judicial Review. Accessed January 18, 2018. http://www.constcourt.md/public/files/file/conferinta_20ani/programul_conferintei/Karin_Bruze lius_2.pdf.

FOLleSDAl, Andreas, and Marlene Wind. "Introduction-Nordic Reluctance towards Judicial Review under Siege.” Nordisk Tidsskrift for Menneskerettigheter 27, no. (2009): 131-41.

GARLICKI, Leszek. "Constitutional Courts versus Supreme Courts." International Journal of Constitutional Law 5, no. 1 (2007): 44-68.

HelgadÓtTIR, Ragnhildur. "Nonproblematic Judicial review: A case study." International Journal of Constitutional Law 9, no. 2 (2011): 532-47.

HIRSCH, Günter. Appointing of Supreme Court Judges. Examination of Situation in Individual Countries. Accessed January 1, 2018. http://network-presidents.eu/sites/default/files/Report_ Hirsch_eng\%5B1\%5D.pdf.

HirsChl, Ran. The Nordic Counternarrative: "Democracy, Human Development and Judicial Review." International Journal of Constitutional Law 9, no. 2 (2011): 449-69.

"Iceland's Judicial System.” Scandinavian Studies in Law 51 (2007): 606-7.

IuUL, Stig. "The Danish Supreme Court Through 300 Years." Scandinavian Studies in Law 6 (1962): 163-83.

Lavapuro, Juha, Tuomas OJAnen, and Martin Scheinin. "Rights-Based constitutionalism in Finland and the Development of Pluralist Constitutional Review." International Journal of Constitutional Law 9, no. 2 (2011): 505-31.

LindBlom, Per H. Studier i procesrätt. Stockholm: Fritzes, 1993. 
Lindblom, Per H. "The Role of the Supreme Courts in Scandinavia." Scandinavian Studies in Law 39 (2000): 325-66.

ModeEn, Tore. "The Founding of the Supreme Administrative Court in Finland set Against its Historical Background in Sweden and Finland." Scandinavian Studies in Law 21 (1977): 209-40.

NERGELIUS, Joakim. "Om grundlagstolkning, grundlagsvänlig lagtolkning och åsidosättande av grundlagsstridig lag." Svensk Juristtidning 81 (1996): 835-71.

Nouisiainen, Jaakko: "The Role of the Finnish Supreme Court in the Legislative Process." Scandinavian Studies in Law 23 (1979): 131-48.

Organy i korporacje ochrony prawa. Edited by Viktoria Serzhanova and Stanisław Sagan. Warszawa: LexisNexis, 2014.

SARvilinNA, Sami. "Court Administration in Finland." Scandinavian Studies in Law 51 (2007): $591-605$.

Serzhanova, Viktoria, and Stanislaw SAGAn. Nauka o państwie wspótczesnym. Warszawa: LexisNexis, 2013.

SERZHANOVA, Viktoria. "Sądy w państwach nordyckich.” In Saqdownictwo w Europie w XIX i XX wieku, edited by Ewa Leniart, Renata Swirgoń-Skok, and Władysław Piotr Wlaźlak, 147-67. Kraków: Bikstudio Krzysztof M. Szwaczka, 2016.

Sмiтh, Eivind. Hфesterett og folkestyret. Prøvningsretten overfor lover. Oslo: Universitetsforlaget, 1993.

Smolej, Mirka, and Jon T. Johnsen. Time Management of Justice Systems: a Northern Europe Study. Accessed January 18, 2018. https://www.coe.int/t/dghl/cooperation/cepej/Delais/Gestion Temps_en.pdf.

STRÖMBERG, Håkan. "Ett HD-fall om prövning av en förordnings grundslagsenlighet." Juridisk Tidskrift 2 (1996-97): 450-52.

Strömholm, Stig. "Goal-Steering and Judicial Review." Scandinavian Studies in Law 40 (2000): 189-97.

Tамm, Ditlev. "Nordic Supreme Courts-Differences and Similarities." In Rule of Law-Development and Judicial Reform: Comparison between China and Finland (Beijing: Social Sciences Academic Press China, 2016): 112-20.

Tамm, Ditlev. "Nordic Unity and Nordic Supreme Courts: Differences and Similarities." In Unity and Plurality in the Legal History of the Baltic Sea Area, edited by Marju Luts-Sootak, Sanita Osipova, and Frank L. Schäfer, 287-94. Frankfurt am Main-Bern-Brussels-New York-OxfordVienna: Peter Lang, Internationaler Verlag der Wissenschaften, 2012.

“The Danish Courts - an Organisation in Development." Scandinavian Studies in Law 51 (2007): 581-90.

The Supreme Court of Norway. Separation of Powers and Independence of Constitutional Courts and Equivalent Bodies, the $2^{\text {nd }}$ Congress of the World Conference on Constitutional Justice. Accessed January 18, 2018. http://www.venice.coe.int/WCCJ/Rio/Papers/NOR_Supreme_Court.pdf.

“The Swedish National Courts Administration.” Scandinavian Studies in Law 51 (2007): 629-50.

TRYGgVadótTIR, Rán, and Thordis IngAdótTIR. Researching Icelandic Law. Accessed January 18, 2018. http://www.nyulawglobal.org/globalex/Iceland.html.

Von Eyben, W.E. The Attitude towards Judicial Precedent in Danish and Norwegian Courts, Scandinavian Studies in Law 3 (1959): 53-86. 
Westerberg, Ole. "Judicial Review of Administrative Decisions." Scandinavian Studies in Law 16 (1972): 307-26.

ZAHLE, Henrik. "Judicial Opinion Writing in the Danish Supreme Court (Højesteret)." Scandinavian Studies in Law 51 (2007): 559-80.

\section{SUPREME COURT SYSTEMS IN THE NORDIC COUNTRIES. AN OUTLINE OF THE ISSUE}

\section{Summary}

The aim of the study is to provide a comparative analysis of the role and tasks that the supreme courts perform in the Nordic legal and political systems. The main focus of the paper is on considerations of the tasks, goals, role and functions of the supreme courts in the Nordic countries, as well as the principles of organisation and functioning on which the supreme court systems in this region of Europe are based. An important part of this study covered the determination of common features and differences that can be seen when comparing countries of the eastern and western Nordic legal culture.

Keywords: supreme courts; Nordic countries; role, tasks and functions; organisation and activity; Nordic legal systems; western and eastern Scandinavian countries; Nordic legal culture.

\section{Translated by Tomasz Patkowski}

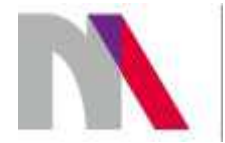

The preparation of the English version of Roczniki Nauk Prawnych (Annals of Iuridical Sciences) and its publication in electronic databases was financed under contract no. 836/PDUN/2018 from the resources of the Minister of Science and Higher Education for the popularization of science. 